\title{
UJI PERBEDAAN KADAR LAKTOSA PADA SUSU FORMULA DAN SUSU FERMENTASI YANG DIPERJUALBELIKAN DI SUPERMARKET KOTA MAKASSAR
}

\author{
Rahmawati $^{1)}$, Nurlia Naim ${ }^{2)}$, Nurhidayat ${ }^{1)}$, Musfirah Hadisul Irham ${ }^{1)}$ \\ 1) Program Studi D3 Teknologi Laboratorium Medis Politeknik Kesehatan Muhammadiyah \\ Makassar \\ 2) Poltekkes Kemenkes Makassar \\ Alamat korespondensi: rahmawatiamma60@gmail.com
}

\begin{abstract}
Abstrak
Susu merupakan sumber nutrisi yang penting untuk pertumbuhan bayi mammalia, termasuk manusia, yang mengandung karbohidrat (laktosa), protein, lemak, mineral dan vitamin. Susu termasuk sumber gizi utama yang dibutuhkan oleh manusia dengan enyusun utama dari susu sapi secara umum adalah air (87,10\%), laktosa (4,8\%), lemak (3,9\%) yang didominasi oleh lemak jenuh, protein susu (3,4\%), dan kadar abu (0,72\%). Penelitian ini bertujuan untuk menentukan perbedaan antara kadar laktosa pada susu formula dengan susu fermentasi menggunakan teknik pengambilan sampel secara random sampling. Pemeriksaan kadar laktosa dilakukan dengan analisis kuantitatif menggunakan metode iodometri. Data yang diperoleh dari penelitian ini dianalisis dengan uji Independent t-test untuk mengetahui perbedaan kadar laktosa pada susu formula dan susu fermentasi. Berdasarkan hasil penelitian diperoleh rata-rata kadar laktosa pada susu formula sebesar 22,063\% dan susu fermentasi sebesar 9,964\%. Hasil uji independent t-test menunjukkan bahwa nilai t-hitung > t-table $(11.623$ > 2.101). Sehingga Ho ditolak dan Ha diterima dengan demikian dapat disimpulkan bahwa ada perbedaan yang signifikan antara kadar laktosa susu formula dengan susu fermentasi.
\end{abstract}

Kata Kunci: Susu Formula, Susu Fermentasi, Iodometri, Uji Independent t-test

\section{PENDAHULUAN}

Susu adalah cairan yang dihasilkan oleh kelenjar susu mamalia dan manusia yang komponen-komponennya tidak dikurangi dan tidak ditambahkan bahanbahan lain. Susu merupakan hasil pemerahan dari ternak sapi perah atau dari ternak menyusui lainnya yang diperah secara kontinu dan komponenkomponennya tidak dikurangi dan tidak ditambahkan bahan-bahan lain. Komponen utama susu terdiri dari air, protein, lemak, karbohidrat, mineral dan vitamin. Komponen-komponen lainnya yang terkandung dalam susu yang jumlahnya sedikit tetapi penting antara lain lesitin, kolesterol, dan asam-asam organik (Depkes RI, 2005).

Menurut Suhendar dkk (2008) komposisi rata-rata susu sapi terdiri dari: Air $83,3 \%$, protein $3,2 \%$, lemak 4,3\%, karbohidrat 3,5\%, kalium 4,3 mg/100 g, kalsium 143,3 mg/100 g, fosfor $60 \mathrm{mg} / 100$ $\mathrm{g}$, besi $1,7 \mathrm{mg} / 100 \mathrm{~g}$, vitamin A, SI 130, Vitamin B1 0,3 mg/100 g dan vitamin C $1 \mathrm{mg} / 100 \mathrm{~g}$. Lemak tersusun dari trigliresida yang merupakan gabungan gliserol dan asam-asam lemak. Dalam lemak susu terdapat $60-75 \%$ lemak yang bersifat jenuh, 25-30\% lemak yang bersifat tak jenuh dan sekitar $4 \%$ merupakan asam lemak polyunsaturated. Komponen mikro lemak susu antara lain adalah fosfolipid, sterol, tokoferol (vitamin E), karoten, serta vitamin A dan D.

Salah satu komponen penting bagi tubuh yang terdapat didalam susu adalah karbohidrat. Karbohidrat merupakan senyawa organik yang terdiri dari unsur karbon, hidrogen, dan oksigen. Klasifikasi karbohidrat ialah monosakarida, disakarida, oligosakarida, dan polisakarida. Salah satu klasifikasi karbohidrat yaitu disakarida yang memiliki jenis sukrosa, maltosa, trehalosa 
dan laktosa yang sangat membantu pada proses metabolisme tubuh. Laktosa merupakan bagian karbohidrat yang terkandung di dalam susu dengan jumlah yang banyak.

Laktosa merupakan gula alamiah yang terkandung dalam minuman dan makanan yang selalu dikonsumsi seharihari seperti roti, biskuit, sereal sarapan, mentega, dan susu. Seperti yang kita ketahui dengan mengkonsumsi laktosa dapat berdampak baik bagi tubuh. Laktosa yang dikonsumsi akan dicerna oleh enzim laktase didalam tubuh menjadi galaktosa dan glukosa sehingga dapat membantu penyerapan natrium dan kalsium serta memberi efek positif terhadap fisiologi usus. Namun tubuh memiliki perbedaan dalam kemampuan mengelolahnya, sehingga setiap manusia membutuhkan laktosa dengan kadar yang berbeda pula (Sumoprastowo, 2000).

Dalam kondisi normal, ketika laktosa mencapai sistem pencernaan, enzim laktase akan segera bekerja memecah laktosa menjadi glukosa dan galaktosa. Galaktosa sendiri oleh hati akan diubah menjadi glukosa dan akan meningkatkan kadar gula dalam darah. Namun pada beberapa kasus ada yang terlahir tanpa kemampuan memproduksi enzim laktase, sehingga tidak mampu mencerna laktosa dan akan berdampak buruk bagi tubuh. Laktosa yang tidak dicerna dengan baik akan masuk kedalam pencernaan bagian usus dan menumpuk sehingga akan mengakibat kram pada bagian perut dan diare. Hal ini dapat dijadikan acuan dalam memilih produk susu yang tepat bagi tubuh dengan melihat kadar laktosa yang terkandung (Suwito, 2010).

Kadar laktosa dalam susu sangat bervariasi antara satu mammalia dengan yang lain. ASI mengandung 7\% laktosa, sedangkan susu sapi hanya mengandung $4 \%$. Laktosa merupakan sumber energi yang memasok hampir setengah keseluruhan kalori susu $(35-45 \%)$. Di samping itu laktosa juga penting untuk absorpsi kalsium (Sudarmadji, 2003).

Gula pereduksi merupakan golongan gula (karbohidrat) yang dapat mereduksi senyawa-senyawa penerima elektron, contohnya adalah glukosa dan fruktosa. Ujung dari suatu gula pereduksi adalah ujung yang mengandung gugus aldehida atau keton bebas. Semua monosakarida (glukosa, fruktosa, galaktosa) dan disakarida (laktosa, maltosa), kecuali sukrosa dan pati (polisakarida), termasuk sebagai gula pereduksi. Metode Luff Schoorl merupakan salah satu metode untuk penentuan gula pereduksi (Underwood, 1993).

Penelitian ini bertujuan untuk mengetahui perbedaan kadar laktosa pada susu formula dan susu fermentasi.

\section{METODE PENELITIAN}

\section{Alat dan Bahan}

Alat yang digunakan untuk penetapan kadar laktosa adalah Timbangan analitik, Hot Plate, Buret 50 $\mathrm{mL}$, termometer, Labu Ukur $100 \mathrm{~mL}, 250$ $\mathrm{mL}, 1000 \mathrm{~mL}$, Gelas Ukur $100 \mathrm{~mL}$, Pipet Volume $10 \mathrm{~mL}, 25 \mathrm{~mL}$, Corong, Sendok tanduk, Erlemeyer, dan Gelas Kimia 200 $\mathrm{mL}, 400 \mathrm{~mL}$.

Bahan yang digunakan adalah susu formula dan susu fermentasi, $\mathrm{H}_{2} \mathrm{SO}_{4} 6 \mathrm{~N}$, Naatrium thiosulfat 0,1N, KI 20\%, kalium iodat, $\mathrm{Na}_{2} \mathrm{CO}_{3}$, asam sitrat, $\mathrm{CuSO}_{4}$, amylum $0,5 \%$, aquadest, dan larutan luff schoorl.

\section{Standarisasi $\mathrm{Na}_{2} \mathrm{~S}_{2} \mathrm{O}_{3}$ dengan $\mathrm{KIO}_{3}$}

Kristal Kalium yodat ditimbang sebanyak 0,2 gr, kemudian dimasukkan kedalam labu ukur $50 \mathrm{ml}$. Ditambahkan aquades kocok hingga larut. Setelah larut ditambahkan aquades sampai tanda batas. Kemudian dimasukkan $10 \mathrm{ml} \mathrm{KIO}_{3} 0,1 \mathrm{~N}$ ke dalam labu erlemeyer $250 \mathrm{ml}$, setelah itu ditambahkan $10 \mathrm{ml} \mathrm{KI} 10 \%$ dan $8 \mathrm{ml}$ $\mathrm{H}_{2} \mathrm{SO}_{4}$. Selanjutnya larutan dititrasi dengan $\mathrm{Na}_{2} \mathrm{~S}_{2} \mathrm{O}_{3} \quad 0,1 \quad \mathrm{~N}$ sampai warna kuning muda kemudian ditambahkan indikator amilum $1 \%$ setelah itu dititrasi 
lagi dengan $\mathrm{Na}_{2} \mathrm{~S}_{2} \mathrm{O}_{3} 0,1 \mathrm{~N}$ sampai warna biru tepat hilang.

\section{Penetapan Kadar Laktosa}

Ditimbang kurang lebih $1 \mathrm{gr}$ sampel (Susu), dimasukkan ke dalam labu ukur $100 \mathrm{ml}$ kemudian sampel dilarutkan dengan sedikit air panas dan ditambahkan dengan aquades hingga garis batas. Larutan dipipet $10 \mathrm{ml}$, dimasukkan ke dalam erlemeyer setelah itu ditambahkan $15 \mathrm{ml}$ aquades dan $25 \mathrm{ml}$ larutan Luff Schoorl kemudian dipanaskan hingga mendidih dan ditunggu 10 menit lalu didinginkan. Setelah itu ditambahkan 15 $\mathrm{ml} \quad \mathrm{H}_{2} \mathrm{SO}_{4} \quad 25 \%$ sedikit demi sedikit ditunggu sejenak hinggah buih menghilang dan ditambahkan KI 20\% sebanyak $10 \mathrm{ml}$ kemudian dititrasi dengan Natrium Thiosulfat $0,1 \mathrm{~N}$ hingga warna kuning muda, ditambahkan amilum, titrasi dilanjutkan hingga warna biru tepat menghilang. Setelah itu dicatat volume titrasi dan dihitung kadar laktosa.

\section{Penetapan Blanko}

Dipipet $10 \mathrm{ml}$ aquadest kemudian ditambahkan larutan Luff Schoorl sebanyak $25 \mathrm{ml}$ kemudian dipanaskan hingga mendidih dan ditunggu 10 menit lalu didinginkan kemudian ditambahkan $15 \mathrm{ml} \mathrm{H}_{2} \mathrm{SO}_{4} 25 \%$ sedikit demi sedikit ditunggu sejenak hingga buih menghilang kemudian ditambahkan KI 20\% sebanyak $10 \mathrm{ml}$ lalu dititrasi dengan Natrium Thiosulfat $0,1 \mathrm{~N}$ hingga warna kuning muda, ditambahkan amilum, titrasi dilanjutkan hingga warna biru tepat menghilang. Setelah itu dicatat volume titrasi dan dihitung kadar laktosa.

\section{Analisis Data}

Data dianalisa berdasarkan hasil pemeriksaan labolatorium kadar laktosa dalam susu kemudian pengujian menggunakan statistik uji $\mathrm{t}$ tidak berpasangan (independent t-test).

\section{HASIL DAN PEMBAHASAN}

Berdasarkan hasil penelitian yang dilakukan diperoleh bahwa rata-rata kadar laktosa pada susu formula dan susu fermentasi masing-masing adalah 22.063 $\%$ dan $9.964 \%$. Kadar laktosa pada susu formula dan susu fermentasi dapat dilihat pada Tabel 1 .

\begin{tabular}{|c|c|c|}
\hline \multirow[b]{2}{*}{ Sampel } & \multicolumn{2}{|c|}{ Kadar Laktosa (\%) } \\
\hline & $\begin{array}{c}\text { Susu } \\
\text { Formula }\end{array}$ & $\begin{array}{c}\text { Susu } \\
\text { Fermentasi }\end{array}$ \\
\hline Susu A & 23.58 & 11.0 \\
\hline Susu B & 21.73 & 9.52 \\
\hline Susu C & 22.10 & 12.85 \\
\hline Susu D & 27.65 & 9.52 \\
\hline Susu E & 21.73 & 12.48 \\
\hline Susu F & 20.62 & 11.74 \\
\hline Susu G & 19.88 & 7.67 \\
\hline Susu H & 24.69 & 8.41 \\
\hline Susu I & 18.77 & 9.15 \\
\hline Susu J & 19.88 & 7.30 \\
\hline Jumlah & 220.63 & 99.64 \\
\hline Rata-Rata & 22.063 & 9.964 \\
\hline $\begin{array}{l}\text { Jumlah } \\
\text { Samnel }\end{array}$ & 10 & 10 \\
\hline
\end{tabular}

Pemeriksaan kadar laktosa dengan metode iodometri (Luff Schoorl) pada dasarnya memiliki prinsip bahwa sampel ditambahkan Luff Schoorl berlebihan, kelebihan larutan Luff Schoorl dititrasi dengan larutan baku Natrium Thiosulfat. Kadar dihitung dengan menggunakan daftar laktosa. Laktosa merupakan satusatunya karbohidrat (gula) yang terdapat pada susu. Laktosa termasuk salah satu gula pereduksi, sehingga kadarnya dapat dihitung secara kuantitatif dengan menggunakan metode tersebut.

Pada penentuan metode ini, yang ditentukan bukannya kuprooksida yang mengendap tapi dengan menentukankuprioksidadalam larutan sebelum direaksikan dengan gula pereduksi (titrasi blanko) dan sesudah direaksikan dengan sampel gula pereduksi (titrasi sampel). Penentuan titrasi dengan menggunakan larutan natrium tiosulfat. Selisih titrasi blanko dengan titrasi sampel ekuivalen dengan kuprooksida yang terbentuk dan juga ekuivalen dengan 
jumlah gula reduksi yang ada dalam bahan / larutan.

$$
\begin{aligned}
& \mathrm{R}-\mathrm{COH}+2 \mathrm{CuO} \\
& \mathrm{Cu}_{2} \mathrm{O}(\mathrm{s})+\mathrm{R}-\mathrm{COOH}(\mathrm{aq}) \\
& \mathrm{C}_{2} \mathrm{SO}_{4}(\mathrm{aq})+\mathrm{CuO} \\
& \mathrm{CuSO}_{4}(\mathrm{aq})+\mathrm{H}_{2} \mathrm{O}(\mathrm{l}) \\
& \mathrm{CuSO}_{4}(\mathrm{aq})+2 \mathrm{KI}(\mathrm{aq}) \\
& \mathrm{CuI}_{2}(\mathrm{aq})+\mathrm{K}_{2} \mathrm{SO}_{4}(\mathrm{aq}) \\
& 2 \mathrm{CuI}(\mathrm{aq}) \\
& \mathrm{Cu}_{2} \mathrm{I}_{2}+\mathrm{I}_{2} \\
& \mathrm{I}_{2}+\mathrm{Na}_{2} \mathrm{~S}_{2} \mathrm{O}_{3} \\
& \mathrm{Na}_{2} \mathrm{~S}_{4} \mathrm{O}_{6}+\mathrm{NaI}
\end{aligned}
$$

Reaksi yang terjadi selama penentuan kadar laktosa adalah kuprooksida yang ada dalam reagen akan membebaskan iod dari garam kalium iodida. Banyaknya iod yang dibebaskan ekuivalen dengan banyaknya kuprioksida. Banyaknya iod dapat diketahui dengan titrasi dengan menggunakan larutan natrium tiosulfat. Untuk mengetahui bahwa titrasi sudah cukup maka diperlukan indikator amilum. Apabila larutan berubah warnanya dari biru menjadi putih, adalah menunjukkan bahwa titrasi sudah selesai, sehingga diperoleh volume masing-masing sampel susu. Selisih volume $\mathrm{Na}_{2} \mathrm{~S}_{2} \mathrm{O}_{3}$ yang digunakan untuk titrasi larutan blanko dengan titrasi larutan sampel setara dengan kadar laktosa total yang terdapat pada susu.

Perbedaan rata-rata kadar laktosa pada susu dapat dilihat pada diagram batang dibawah ini yang menunjukkan bahwa kadar laktosa pada susu formula lebih tinggi dibandingkan dengan susu fermentasi.

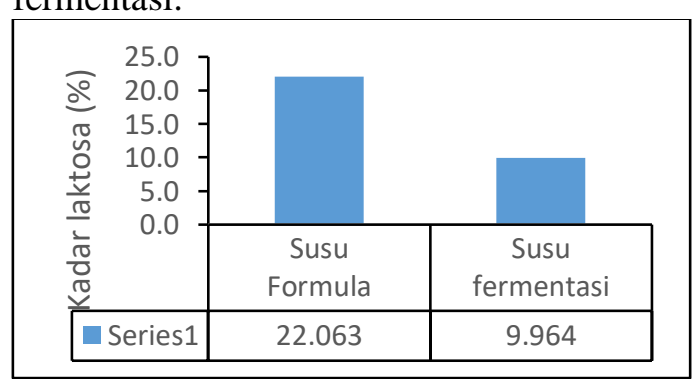

Gambar 1. Grafik Perbedaan Rata-Rata

Kadar Laktosa pada Susu
Susu formula adalah susu yang dibuat dari susu sapi atau susu buatan yang diubah komposisinya hingga dapat memenuhi kebutuhan tubuh seperti yang terkandung pada susu sapi. Susu fermentasi adalah produk susu yang diperoleh dari fermentasi susu segar dengan atau tanpa pasteurisasi, susu rekonstitusi atau susu rekombinasi yang diperoleh dari fermentasi dengan bakteri asam laktat yang sesuai.

Laktosa merupakan bentuk disakarida dari karbohidrat yang dapat dipecah menjadi bentuk lebih sederhana yaitu galaktosa dan glukosa. Laktosa, $\beta$ galacotse 1,4 glukosa merupakan komposisi gula pada susu mammalia yang unik yang memberi rasa manis pada susu (Solomons, 2002).

Adanya perbedaan yang signifikan antara susu formula dan susu fermentasi disebabkan oleh perbedaan proses pembuatan antara keduanya sehingga komposisi yang terkandung oleh keduanya juga berbeda. Susu formula memiliki kadar laktosa yang lebih tinggi karena pada proses pembuatan komposisi diubah sedemikian mungkin sehingga dapat memenuhi kebutuhan tubuh. Akibatnya banyak kasus yang mengalami intoleransi latosa setelah mengkomsumsi Susu Formula sedangkan Susu Fermentasi memiliki kadar yang lebih rendah karena proses pembuatannya yang dibiarkan membusuk secara alami sehingga komposisinya dalam jumlah rendah. Hal ini dapat dibuktikan oleh rasa Susu Fermentasi yang cenderung terasa asam karena glukosa yang berperan sebagai pemanis terdapat dalam jumlah rendah (Surono, 2004). 
Tabel 2. Hasil Pengujian Statistik menggunakan Uji-t Tidak Berpasangan

\begin{tabular}{cccccc}
\hline Sampel & N & Mean & SD & t hitung & $\begin{array}{c}\text { T } \\
\text { tabel }\end{array}$ \\
\hline $\begin{array}{c}\text { Susu } \\
\text { Formula } \\
\text { Susu }\end{array}$ & 10 & 22.063 & 2.647 & 11.623 & 2.101 \\
Fermentasi & 10 & 9.964 & 1.963 & & \\
\hline
\end{tabular}

Dari hasil perhitungan diperoleh angka t hitung 11.623 sedangkan t-table 2.101. Ini menunjukkan $\mathrm{t}$ hitung lebih besar dari t table. Artinya Ho ditolak dan Ha diterima yaitu adanya perbedaan yang signifikan antara kadar laktosa pada Susu Formula dan Susu Fermentasi.

\section{KESIMPULAN}

Berdasarkan hasil penelitian yang telah dilakukan diperoleh bahwa hasil pengujian statistik antara kadar laktosa yang terkandung pada Susu Formula dan Susu Fermentasi berdasarkan uji t tidak berpasangan yaitu $\mathrm{t}$ hitung $>\mathrm{t}$ table $(11.623>2.101)$. Sehingga Ho ditolak dan Ha diterima dengan demikian dapat disimpulkan bahwa ada perbedaan yang signifikan diantara keduanya

\section{DAFTAR PUSTAKA}

Departemen Kesehatan RI , 2005. Tentang Peningkatan Mutu Pada Susu yang Beredar Di Indonesia.

Solomons, N. W. 2002. Fermentation, Fermented Foods And Lactose Intolerance. European Journal of Clinical Nutrition, 56 (2): 50-55.

Sudarmaji, S. 2003. Analisis Bahan Makanan dan Minuman. Yogyakarta: Liberty Yogyakarta

Sumoprastowo. 2000. Pemilihan Nutrisi dalam Makanan dan Minuman. Jakarta: Bumi Aksara

Surono. 2004 . Probiotik Susu Fermentasi dan Kesehatan. Jakarta: Yayasan Pengusaha Makanan dan Minuman Seluruh Indonesia

Suhendar. 2008. Pasca Panen Lalai Kualitas Susu Terbengkalai. Bandung: Institut Mikrobiologi Pangan.
Suwito, W. 2010, Bakteri yang Sering Mencemari Susu: Deteksi, Patogenesis, Epidemiologi, dan Cara Pengendaliannya, Balai Pengkajian Teknologi Pertanian Yogyakarta, Jurnal Litbang Pertanian, 29 (3): hal. 96-100.

Underwood, A.L. 1992. Analisis Kimia Kuantitatif. Universitas Erlangga. Jakarta. 